\title{
T-Cell Leukemia Homeobox Protein 1
}

National Cancer Institute

\section{Source}

National Cancer Institute. T-Cell Leukemia Homeobox Protein 1. NCI Thesaurus. Code C17497.

T-cell leukemia homeobox protein 1 (330 aa, $34 \mathrm{kDa}$ ) is encoded by the human TLX1 gene. This protein plays a role in the modulation of transcription. 